\title{
Dermatology
}

Alkhalaf, A. 17

Cattin, V. 4

Clayton, H. 7

Feldmeyer, L. 24

Gadaldi, K. 24

Gaide, O. 4, 7

Girardin, M. 7

Guillod, C. 9
Hofbauer, G.F.L. IV, 14, 17

Hunger, R.E. 24, 29

Kuonen, F. 7

Laffitte, E. 1

Leoni-Parvex, S. $9 \quad$ Yawalkar, N. 24

Mainetti, C. 9

Masouyé, I. 1

Mohanna, M.T. 14
Mühlstädt, M. 1, 20

Stieger, M. 29

Tzika, E. 1

\section{Subject Index Vol. 232, Suppl 1, 2016}

Actinic keratosis 4, 7, 14, 20

Basal cell carcinoma 29

Basal cell nevus syndrome 29

Bowen's disease 9, 14, 17

Cheekbones 4

Chronic actinic cheilitis 1

Conjunctivitis 4

Daylight photodynamic therapy 20

Dermoscopy 9

Field cancerization 7,20
Gorlin syndrome 29

Healing 4

Imiquimod 1

Immunosuppression 7, 20

Ingenol mebutate $1,4,7,9,14,17,20,24$, 29

Lentigo maligna 24

LLC 7

Melanoma 24

Methyl aminolevulinate 20
Non-melanoma skin cancers 9

Photodynamic therapy $1,17,20$

PTCH1 gene mutation 29

Scalp 7

Side effects 4

Treatment 24

Vismodegib 29 